\title{
LOAD-DEFLECTION CHARACTERISTICS OF STEEL, POLYPROPYLENE AND HYBRID FIBER REINFORCED CONCRETE BEAMS
}

\author{
M. TAMIL SELVI ${ }^{1}$, T. S. THANDAVAMOORTHY ${ }^{2}$
}

Concrete is the most widely used construction material because of its specialty of being cast into any desired shape. The main requirements of earthquake resistant structures are good ductility and energy absorption capacity. Fiber reinforced concrete possesses high flexural and tensile strength, improved ductility, and high energy absorption over the conventional concrete in sustaining dynamic loads. The aim of this paper is to compare the properties of concrete beams in which three types of fibers are added individually. Steel fibers, polypropylene fibers and hybrid fibers were added to concrete in the weight ratio of four percentages in the preparation of four beam specimens. The fourth specimen did not contain fibers and acted as a control specimen. The dimensions of the beam specimens were $150 \mathrm{~mm} \times 150 \mathrm{~mm} \times 700 \mathrm{~mm}$. The reinforced concrete beams of M30 grade concrete were prepared for casting and testing. Various parameters such as load carrying capacity, stiffness degradation, ductility characteristics and energy absorption capacity of FRC beams were compared with that of RC beams. The companion specimens were cast and tested to study strength properties and then the results were compared. All the beams were tested under three point bending under Universal Testing Machine (UTM). The results were evaluated with respect to modulus of elasticity, first crack load, ultimate load, and ultimate deflection. The test result shows that use of hybrid fiber improves the flexural performance of the reinforced concrete beams. The flexural behavior and stiffness of the tested beams were calculated, and compared with respect to their load carrying capacities. Comparison was also made with theoretical calculations in order to determine the load-deflection curves of the tested beams. Results of the experimental programme were compared with theoretical predictions. Based on the results of the experimental programme, it can be concluded that the addition of steel, polypropylene and hybrid fibers by $4 \%$ by weight of cement (but $2.14 \%$ by volume of cement) had the best effect on the stiffness and energy absorption capacity of the beams.

\footnotetext{
${ }^{1} \mathrm{PhD}$ Scholar and Associate Professor, Department of Civil Engineering, Dr. M.G.R. Educational and Research Institute University, Chennai 600095, India,e-mail: tamilselvi_05@yahoo.com(corresponding author) ${ }^{2}$ Professor, Department of Civil Engineering, Adhiparasakthi Engineering College ,Melmaruvathur , India, e-mail: tan_44@yahoo.com
} 
Keywords: steel fiber, polypropylene fiber, modulus of elasticity, load deflection curve and stiffness

\section{INTRODUCTION}

Concrete is the most widely used man-made construction material. Plain concrete possesses a very low tensile strength, limited ductility and little resistance to cracking. Conventional concrete doesn't meet many functional requirements such as impermeability, resistance to frost adequately, etc. The presence of micro cracks at the mortar-aggregate interface is responsible for the inherent weakness of plain concrete. Because of the poor tensile strength, cracks propagate with the application of load, leading to brittle fracture of concrete. Micro cracks are formed in concrete during hardening stage. These deficiencies have led researchers to investigate and develop a material which could perform better in areas where conventional concrete has several limitations. Natural disasters like earthquakes, cyclones, tsunami, and so on so forth destroy the high rise buildings, bridges, monumental structures, world wonders, etc. To protect the world from this kind of devastation, the field of civil engineering requires some innovations in both materials and construction techniques. One such development was two phase composite materials i.e., fiber reinforced concrete, in which cement based matrix is reinforced with ordered or random distribution of fibers. Fiber in the cement based matrix acts as crack arresters which restrict the growth of flaws in the matrix, preventing these from enlarging under load, into cracks, which eventually cause failure. The weakness can be removed by inclusion of fibers in concrete. The fibers help to transfer loads at the internal micro cracks. Fibers like steel, glass, polypropylene, recron $3 \mathrm{~s}$ and nylon have been tried. It is known that concrete is relatively a brittle material and has serious short-coming of poor toughness. Addition of randomly distributed fibres improves structural characteristics of concrete, viz., static flexural strength, ductility, flexural toughness, etc., which depend upon type, size, aspect ratio and volume fractions of the fibers used. The aim of structural design is to design a structure so that it fulfils three criteria, namely, safety in terms of strength, stability and structural integrity; adequate serviceability in terms of stiffness, durability, deformation and economy. The behavior of the section at various stages of loading can be studied in two parts, i.e., initial uncracked phase and the ultimate condition at collapse [1]. Recent years have seen considerable interest in the fiber hybridization - particularly, combinations of metallic and non-metallic fibers. For optimal behavior, different types of metallic and non-metallic fibers have been combined. The mechanical properties such as compressive strength, flexural strength and flexural toughness, 
etc., of Hybrid Fiber Reinforced Concrete (HyFRC) have been investigated by different investigators. Positive synergy between the large size steel and small size polypropylene fibers was reported with regard to load bearing capacity of concrete by Qian and Stroeven [2]. Influence of fiber type and combinations on the crack growth resistance of steel and polypropylene fiber reinforced concrete was reported in an investigation conducted by Banthia and Nandakumar [3]. Fiber reinforced concrete decreases efficiently the brittleness of concrete, and it improves its characteristics. There are two main types of fibers: steel fibers and polypropylene fibers which have been studied in recent years. The ductility of concrete is an important property that can be increased by using steel fiber reinforcement.

Generally, the cost of construction can be reduced by mixing steel fiber into plain concrete thereby increasing the toughness of concrete and its resistance to impact [4]. In past studies, Gonnerman [5] experimentally showed that the ratio of the compressive failure stress to the compressive strength decreases as the specimen size increases. Markeset and Hillerborg [6] and Jansen and Shah [7] also experimentally showed that strength reduction was independent of the specimen size when the specimen height/diameter was greater than a constant value (i.e., $2.0-2.5$ for cylindrical specimens). Currently, Fantilli et al. [8] have studied the size effects on beam ductility caused by the depth of the compression zone. Moreover, based on the previous concept, the fracture mechanics-type size effect for diagonal shear failure of beams [9] and empirical modeling of reinforced concrete (RC) shear strength size effect for members [10] were carried out to verify failures in concrete structures. The actual stress distribution in the compression zone of RC flexural members was extremely difficult to both measure and adequately model [11].

\section{EXPERIMENTAL PROGRAMME}

The concrete mix proportion used in this investigation designed as per IS:10262 [12] and shown in Appendix 1 for casting the test specimens is shown in Table 1. Portland Pozzolana Cement (PPC), crushed stone coarse aggregates with maximum size of $20 \mathrm{~mm}$ and locally available river sand were used. Materials conformed to the Indian Standard Specifications [13]. Crimped steel fibers and polypropylene fibers were used at $4 \%$ by weight of cement $(2.14 \%$ by volume of cement) The specimen used for compressive strength tests were $150 \mathrm{~mm} \times 150 \mathrm{~mm} \times 150 \mathrm{~mm}$ cubes whereas standard prisms of size $100 \mathrm{~mm} \times 100 \mathrm{~mm} \times 700 \mathrm{~mm}$ were used for flexural strength tests. 
Table 1. Concrete Mix Proportion

\begin{tabular}{|c|c|c|c|c|c|}
\hline \multirow{2}{*}{ SI. No } & MATERIAL & \multicolumn{4}{|c|}{ QUANTITY PER M IN KG $^{3}$} \\
\cline { 3 - 6 } & $\begin{array}{c}\text { Conventional } \\
\text { concrete }\end{array}$ & $\begin{array}{c}\text { Steel fiber } \\
\text { reinforced } \\
\text { concrete }\end{array}$ & $\begin{array}{c}\text { Polypropylene } \\
\text { fiber reinforced } \\
\text { concrete }\end{array}$ & $\begin{array}{c}\text { Hybrid fiber } \\
\text { reinforced } \\
\text { concrete }\end{array}$ \\
\hline $\mathbf{1}$ & Cement $\left(\mathrm{kg} / \mathrm{m}^{3}\right)$ & 420 & 420 & 420 & 420 \\
\hline $\mathbf{2}$ & Fine aggregate $\left(\mathrm{kg} / \mathrm{m}^{3}\right)$ & 420 & 420 & 420 & 420 \\
\hline $\mathbf{3}$ & $\begin{array}{c}\text { Coarse aggregate } \\
\left(\mathrm{kg} / \mathrm{m}^{3}\right)\end{array}$ & 840 & 840 & 840 & 840 \\
\hline $\mathbf{4}$ & W/C ratio & 0.45 & 0.45 & 0.45 & 0.45 \\
\hline $\mathbf{5}$ & Steel fibre $(\mathrm{kg})$ & - & 16.8 & - & - \\
\hline $\mathbf{6}$ & $\begin{array}{c}\text { Polypropylene fiber } \\
(\mathrm{kg})\end{array}$ & - & - & 16.8 & - \\
\hline $\mathbf{7}$ & Hybrid fiber $(\mathrm{kg})$ & - & 8.4 & 8.4 & Total = 16.8 \\
\hline
\end{tabular}

\subsection{DESIGN DETAILS OF BEAMS}

Beams of cross-sectional dimension $150 \mathrm{~mm} \times 150 \mathrm{~mm}$ and length of $700 \mathrm{~mm}$ were cast for testing. Three categories of beams as detailed below were prepared.

1) Beam without reinforcement: Here no longitudinal reinforcement bars were provided

2) Singly reinforced beam: Main reinforcement bars, 2 Nos. $12 \mathrm{~mm}$ dia, Fe415 steel on the tension side were provided (Fig. 1).

3) Doubly reinforced beam: Main reinforcement bars, 2 Nos. $12 \mathrm{~mm}$ dia, Fe415 steel on the tension side; 2 Nos. $8 \mathrm{~mm}$ dia, Fe 250 steel hanger bars on the compression side were provided. At supports and at mid span section, stirrups of $6 \mathrm{~mm}$ dia at $75 \mathrm{~mm} \mathrm{c} / \mathrm{c}$ were provided (Fig. 2).

The specimen dimensions, the reinforcement details and loading conditions are shown in Fig. 1 and Fig. 2, respectively. The specimens were cast with concrete with different types of fibers. The length of steel fiber was $46 \mathrm{~mm}$ and its diameter was $1 \mathrm{~mm}$. The length of polypropylene was $50 \mathrm{~mm}$ and its diameter was $1 \mathrm{~mm}$. Each type of concrete consisted of four standard flexural test specimens and three cubes for determining the 28-day compressive strength of each mix. The specimens for compressive strength tests and the specimens for flexural strength were for 28 days 
using potable water. In fact, this paper is part of a larger investigation being conducted to investigate the flexural characteristics of concrete containing hybrids of steel and polypropylene fibers. Out of each batch of concrete, three specimens were tested under flexural loading to obtain load - deflection relation. This paper reports the results of the modulus of elasticity and load deflection test. Both tests were conducted on $1000 \mathrm{kN} \mathrm{UTM.}$

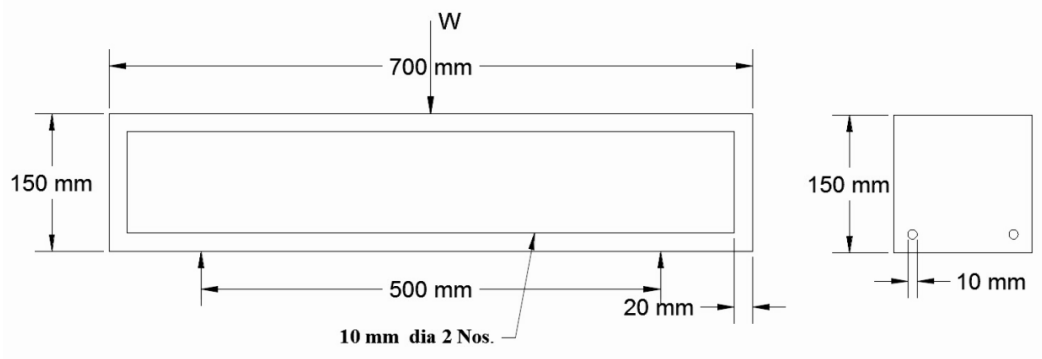

Fig. 1. Test set up for singly reinforced R.C.C. beams

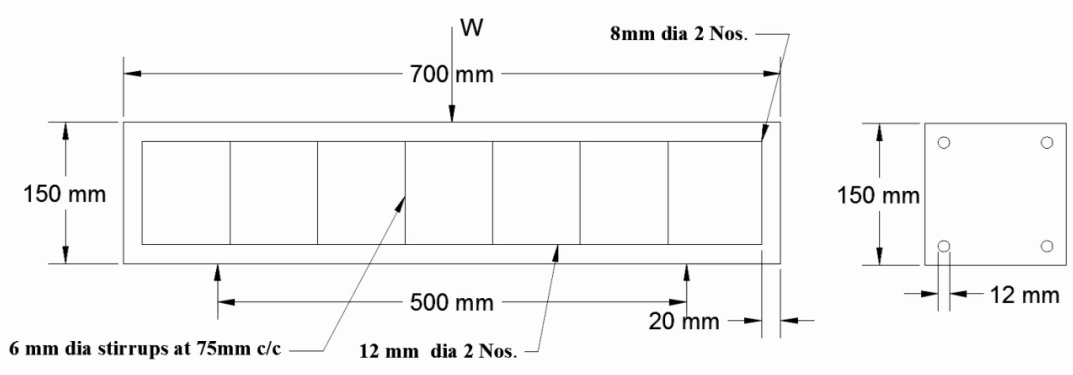

Fig. 2. Test set up for DOUBLY reinforced R.C.C.

\subsection{TESTING OF R.C.C. BEAMS}

The beam was supported over a span of $500 \mathrm{~mm}$ and a single point load was applied at mid span (Fig. 1 and Fig. 2). The specimen was tested till failure and the central deflections of the beam under load increments were recorded for gradually applied load till the ultimate load was reached. Using the load vs deflection data, the corresponding stresses and strains were calculated. The loaddeflection curves for the three locations were plotted. 
1. The strain profile along the depth for different loads was drawn

2. Theoretical and experimental values of maximum deflection of the beam were calculated

3. Theoretical and experimental ultimate loads were calculated

4. Theoretical calculations of cracking load and ultimate load were performed.

\subsection{MODULUS OF ELASTICITY}

The modulus of elasticity (Young's modulus) E is a material property, which describes its stiffness and is therefore one of the most important properties of solid materials. Mechanical deformation puts energy into a material. The energy is stored elastically or dissipated plastically. The way a material stores this energy is summarized in stress-strain curves. Stress is defined as force per unit area and strain as elongation or contraction per unit length. When a material deforms elastically, the amount of deformation also depends on the size of the material, but the strain for a given stress is always the same and the two are related by Hooke's Law (stress is directly proportional to strain): where $\sigma$ is stress (MPa), E modulus of elasticity (MPa), and $\varepsilon$ strain $(\mathrm{mm} / \mathrm{mm}$ or $\%)$. From the Hook's law the modulus of elasticity is defined as the ratio of the stress to the strain.

To determine the modulus of elasticity of concrete, cylindrical specimens were cast and cured for 28 days. The specimens were tested after 28 days in the compression testing machine as per IS 516:1959 [14]. The modulus of elasticity of the specimens was worked out based on the secant modulus of elasticity at one third stress level of ultimate stress. The value of ' $E$ ' determined as in Eq. (1) is given in Tables 2.

$$
\mathrm{E}=\left[\operatorname{Stress}\left(\mathrm{N} / \mathrm{mm}^{2}\right) /\left(\text { Strain } \times 10^{-6}\right)\right]
$$

Table 2. Comparison of Modulus of Elasticity

\begin{tabular}{|c|c|c|c|c|}
\hline \multirow{2}{*}{$\begin{array}{c}\text { Type } \\
\text { of concrete }\end{array}$} & \multicolumn{3}{|c|}{$\begin{array}{l}\text { Modulus of Elasticity - Experimental value } \\
\qquad\left(\mathrm{N} / \mathrm{mm}^{2}\right)\end{array}$} & \multirow{2}{*}{$\begin{array}{c}\text { Modulus of Elasticity } \\
\text { Value as per IS } \\
456: 2000[15] \\
\left(\mathrm{N} / \mathbf{m m}^{2}\right)\end{array}$} \\
\hline & $\begin{array}{l}\text { Without } \\
\text { reinforcement }\end{array}$ & Singly reinforced & Doubly reinforced & \\
\hline $\mathrm{CC}$ & $1.6 \times 10^{5}$ & $1.6 \times 10^{6}$ & $3.58 \times 10^{4}$ & $2.72 \times 10^{4}$ \\
\hline SFRC & $4.5 \times 10^{5}$ & $1.1 \times 10^{6}$ & $5.7 \times 10^{5}$ & $2.72 \times 10^{4}$ \\
\hline PPFRC & $1.76 \times 10^{5}$ & $1.2 \times 10^{6}$ & $1.9 \times 10^{5}$ & $2.72 \times 10^{4}$ \\
\hline HyFRC & $1.53 \times 10^{5}$ & $1.2 \times 10^{6}$ & $2.5 \times 10^{5}$ & $2.72 \times 10^{4}$ \\
\hline
\end{tabular}




\subsection{LOAD-DEFLECTION RELATION}

The beam was supported over a span of $500 \mathrm{~mm}$ and a centre point load was applied. The mechanical gauge beads were fixed in the positions where strains were to be recorded. The beam was placed on the test bench under the UTM with proper alignment (Fig. 3a and 3b). The dial gauges were placed in positions where deflections were to be measured. Load was applied in predetermined incremental values and the displacements and deflections corresponding to each load increment were measured. Formation of cracks was observed during the loading process (Fig. $3 \mathrm{c}$ and 3d). Crack was marked when observed in the beam and the load at which such crack appear was noted. Till failure of the beam, load was applied and the ultimate load was noted down.

(a)

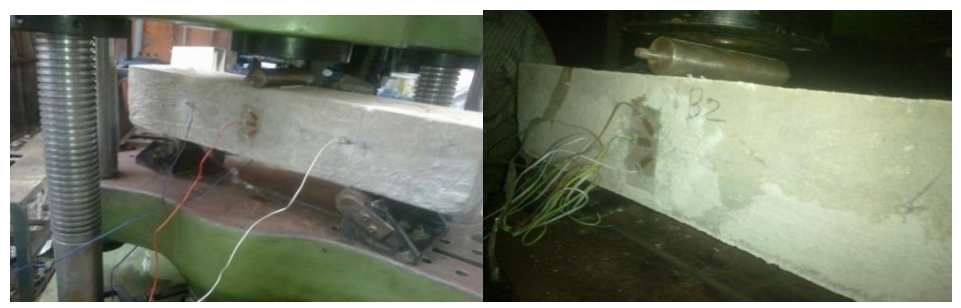

(b)

(c)

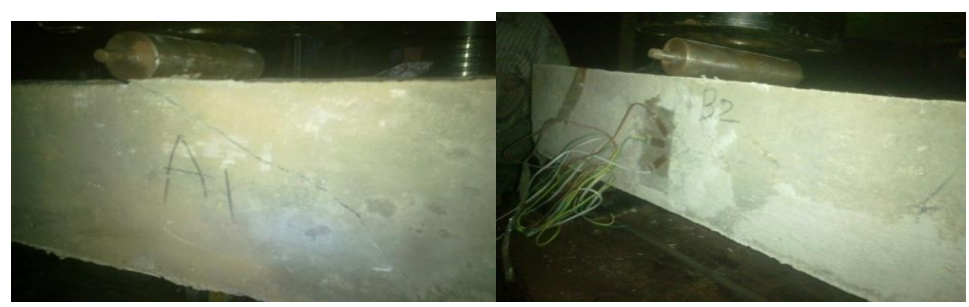

(d)

Fig. 3. Testing of beam

(a) Test set up, (b) Strain gauge instrumentation, (c) Shear crack, (d) Crushing at load support

The results of beams tested without reinforcement, with reinforcement on tension side only and with reinforcements on both sides are shown in Tables 3, 4, 5, respectively. Theoretical deflection of beam was calculated considering it as simply supported beam with a centre point load, $\mathrm{d}=\mathrm{PL}^{3} / 48 \mathrm{EI}, \mathrm{I}=\mathrm{I}_{\mathrm{g}}$, gross moment of inertia for uncracked section and $\mathrm{I}=\mathrm{I}_{\mathrm{cr}}$ for cracked section, where: $\mathrm{P}=$ Load in $(\mathrm{kN}) ; \mathrm{L}=$ Effective length in $(\mathrm{mm}), \mathrm{E}=$ Young's Modulus in $\left(\mathrm{N} / \mathrm{mm}^{2}\right)$; $I_{g}=$ Moment of inertia for gross section or uncraked section, $I_{c r}=$ Moment of Inertia of the cracked 
$=\mathrm{b} \mathrm{k}^{2} \mathrm{jd}^{3} / 2$ [15] where $\mathrm{b}$ is the breadth of the section, $\mathrm{d}-$ is the depth, $\mathrm{k}$ is the depth of compression zone and $\mathrm{j}$ is the lever arm constant. To find the stresses in a cracked beam, the equivalent, purely concrete and transformed section was used. The difference between the analysis of cracked and uncracked sections was that no tensile stresses were allowed in the cracked case. Typical loaddeflection values obtained in this investigation for concrete containing different combinations of fibers are presented in Table 3, 4 and 5 for the beam without reinforcement, for singly reinforced beam and for doubly reinforced beam, respectively. There is an increase in mid span deflection corresponding to peak load as compared to conventional concrete.

Table 3. Results of beams without reinforcements

\begin{tabular}{|c|c|c|c|c|c|c|}
\hline $\begin{array}{c}\text { Type } \\
\text { of Concrete }\end{array}$ & Specimen & $\begin{array}{c}\text { Load at first } \\
\operatorname{crack}(k N)\end{array}$ & $\begin{array}{c}\text { Ultimate } \\
\text { Load }(k N)\end{array}$ & $\begin{array}{c}\text { Deflection at } \\
\text { ultimate load } \\
\text { (mm) }\end{array}$ & $\begin{array}{c}\text { Theoretical } \\
\text { deflection at } \\
\text { ultimate load } \\
\text { (mm) }\end{array}$ & Average \\
\hline \multirow{2}{*}{$\begin{array}{c}\text { Conventional } \\
\text { concrete }\end{array}$} & $\mathrm{A}_{1}$ & 40 & 55 & 0.42 & 0.10 & \multirow{2}{*}{0.100} \\
\hline & $\mathrm{A}_{2}$ & 45 & 60 & 0.46 & 0.10 & \\
\hline \multirow{2}{*}{ Steel FRC } & $\mathrm{B}_{1}$ & 45 & 60 & 0.58 & 0.03 & \multirow{2}{*}{0.035} \\
\hline & $\mathrm{B}_{2}$ & 55 & 65 & 058 & 0.04 & \\
\hline \multirow{2}{*}{$\begin{array}{c}\text { Polypropylene } \\
\text { FRC }\end{array}$} & $\mathrm{C}_{1}$ & 50 & 55 & 1.50 & 0.10 & \multirow{2}{*}{0.100} \\
\hline & $\mathrm{C}_{2}$ & 55 & 60 & 1.50 & 0.10 & \\
\hline \multirow{2}{*}{$\begin{array}{l}\text { HYBRID } \\
\text { FRC }\end{array}$} & $\mathrm{D}_{1}$ & 55 & 60 & 0.48 & 0.10 & \multirow{2}{*}{0.100} \\
\hline & $\mathrm{D}_{2}$ & 55 & 60 & 0.51 & 0.10 & \\
\hline
\end{tabular}

NOTE: $A_{1}, A_{2}$ - Without reinforcement conventional concrete, $B_{1} B_{2}$ - Without main reinforcement Steel fiber reinforced concrete, $C_{1}, C_{2}$ - Without main reinforcement Polypropylene fiber reinforced concrete $D_{1}, D_{2}$ - Without main reinforcement Hybrid fiber reinforced concrete

Table 4. Results of singly reinforced beams

\begin{tabular}{|c|c|c|c|c|c|c|}
\hline $\begin{array}{l}\text { Type of } \\
\text { Concrete }\end{array}$ & Specimen & $\begin{array}{l}\text { Load at first } \\
\text { crack }(k N)\end{array}$ & $\begin{array}{c}\text { Ultimate load } \\
(\mathrm{kN})\end{array}$ & $\begin{array}{c}\text { Deflection at } \\
\text { ultimate load } \\
(\mathrm{mm})\end{array}$ & $\begin{array}{c}\text { Theoretical } \\
\text { deflection at } \\
\text { ultimate load } \\
(\mathrm{mm})\end{array}$ & Average \\
\hline \multirow{2}{*}{$\begin{array}{c}\text { Conventional } \\
\text { concrete }\end{array}$} & $\mathrm{A}_{1-1}$ & 55 & 70 & 1.15 & 2.50 & \multirow{2}{*}{2.50} \\
\hline & $\mathrm{A}_{1-2}$ & 55 & 65 & 0.90 & 2.50 & \\
\hline \multirow{2}{*}{ Steel FRC } & $\mathrm{B}_{1-1}$ & 80 & 99 & 1.50 & 1.75 & \multirow{2}{*}{1.76} \\
\hline & $\mathrm{B}_{1-2}$ & 70 & 95 & 1.45 & 1.78 & \\
\hline \multirow{2}{*}{$\begin{array}{c}\text { Polypropylene } \\
\text { FRC }\end{array}$} & $\mathrm{C}_{1-1}$ & 50 & 70 & 1.90 & 1.50 & \multirow{2}{*}{1.48} \\
\hline & $\mathrm{C}_{1-2}$ & 55 & 76 & 1.95 & 1.45 & \\
\hline \multirow{2}{*}{ HYBRID FRC } & $\mathrm{D}_{1-1}$ & 70 & 80 & 0.90 & 0.92 & \multirow{2}{*}{0.91} \\
\hline & $D_{1-2}$ & 75 & 85 & 0.91 & 0.90 & \\
\hline
\end{tabular}

NOTE: $A_{1-1}, A_{1-2}$-Singly reinforced with conventional concrete, $B_{1-1}, B_{1-2}$ - Singly reinforced with Steel fiber reinforced concrete, $C_{1-1}, C_{1-2}$ - Singly reinforced with Polypropylene fiber reinforced concrete, $D_{1-1}, D_{1-2}$ - Singly reinforced with Hybrid fiber reinforced concrete. 
Table 5. Results of doubly reinforced beams tested with different fibers

\begin{tabular}{|c|c|c|c|c|c|c|}
\hline $\begin{array}{l}\text { Type of } \\
\text { Concrete }\end{array}$ & Specimen & $\begin{array}{l}\text { Load at first } \\
\text { crack }(k N)\end{array}$ & $\begin{array}{l}\text { Ultimate load } \\
\qquad(\mathrm{kN})\end{array}$ & $\begin{array}{l}\text { Deflection at } \\
\text { ultimate load } \\
\qquad(\mathrm{mm})\end{array}$ & $\begin{array}{c}\text { Theoretical } \\
\text { deflection at } \\
\text { ultimate load } \\
(\mathrm{mm})\end{array}$ & Average \\
\hline \multirow{2}{*}{$\begin{array}{l}\text { Conventional } \\
\text { concrete }\end{array}$} & $\mathrm{A}_{2-1}$ & 75 & 90 & 1.08 & 9.0 & \multirow[t]{2}{*}{9.0} \\
\hline & $\mathrm{A}_{2-2}$ & 85 & 97.3 & 1.25 & 9.0 & \\
\hline \multirow{2}{*}{ Steel FRC } & $\mathrm{B}_{2-1}$ & 90 & 115 & 1.61 & 3.2 & \multirow[t]{2}{*}{3.13} \\
\hline & $\mathrm{B}_{2-2}$ & 105 & 118 & 1.75 & 3.06 & \\
\hline \multirow{2}{*}{$\begin{array}{c}\text { Polypropylene } \\
\text { FRC }\end{array}$} & $\mathrm{C}_{2-1}$ & 85 & 99 & 1.43 & 9.42 & \multirow[t]{2}{*}{9.00} \\
\hline & $\mathrm{C}_{2-2}$ & 75 & 95 & 1.43 & 8.63 & \\
\hline \multirow{2}{*}{ HYBRID FRC } & $\mathrm{D}_{2-1}$ & 115 & 150 & 2.20 & 11.15 & \multirow[t]{2}{*}{10.5} \\
\hline & $\mathrm{D}_{2-2}$ & 95 & 120 & 1.56 & 10.00 & \\
\hline
\end{tabular}

NOTE: A2-1, A2-2 - Doubly reinforcement with conventional concrete, $B_{2-1}, B_{2-2}$ - Doubly reinforcement with Steel fiber reinforced concrete, $C_{2-1}, C_{2-2}$ - Doubly reinforcement with Polypropylene fiber reinforced concrete, $D_{2-1}, D_{2-2}$ - Doubly reinforcement with Hybrid fiber reinforced concrete.

\section{RESULTS AND DISCUSSIONS}

The test results of the steel, polypropylene and hybrid fiber reinforced concrete are compared with the conventional concrete. These results are discussed in detail below under various headings.

\subsection{COMPARISON OF MODULUS OF ELASTICITY}

The Modulus of Elasticity (E) of all the three types of concrete made using steel, polypropylene and Hybrid fiber are compared in Table 2.

The value of Modulus of Elasticity (E) as per IS:456 [16] recommendations are calculated for the three concretes and compared in Table 2. From the comparison of Modulus of Elasticity (E) the following points are presented:

1. The experimental value in the case of beams without reinforcing bars and SFRC was higher than $100 \%$, for singly reinforced beam $16 \%$ higher and in the case of doubly reinforced $100 \%$ more than the conventional concrete beam.

2. The value of ' $E$ ' for the PPFRC was $59 \%$ higher for the case of beam without reinforcement, $22 \%$ lower for singly reinforced case and more than $100 \%$, for doubly reinforced concrete beam over the conventional concrete beam.

3. The experimental value of hybrid FRC is higher by $26 \%$ for the case without reinforcement, more than $100 \%$ for single reinforcement and more than $100 \%$ for double reinforcement over the conventional concrete. 


\subsection{Testing OF R.C.C. BEAM}

The presence of steel fiber and polypropylene fiber in concrete did not significantly influence the ultimate strength of the beam and the deflection at the maximum load. Small variation in the ultimate strength was due to changes in the compressive strength of the concrete caused by the addition of fibers. Fibers did not significantly influence the flexural characteristics of the beams before cracking. But the ultimate deflection has significantly increased when steel fibres and polypropylene fibres were used in the concrete beams.

\subsection{ULTIMATE LOAD AND STIFFNESS OF BEAM}

From the testing of R.C.C. beam, the ultimate load for each of the beams made using steel, polypropylene and Hybrid fiber reinforced concrete were compared in Tables 3, 4 and 5. The initial stiffness $\left(\mathrm{k}_{\mathrm{i}}\right)$ and service stiffness $\left(\mathrm{k}_{\mathrm{s}}\right)$ at $50 \%$ of ultimate strength were calculated for all the beams from the load-deflection values from Table 3, 4, 5 values. The theoretical stiffness $\left(\mathrm{k}_{\mathrm{t}}\right)$ of the beam was also determined based on the maximum deflection at mid span subjected to single point loading. Stiffness of simply supported beam can be determined by a simple equation from strength of materials as, $\mathrm{K}=48 \mathrm{EI} / \mathrm{L}^{3}$.

where: $\mathrm{K}=$ Stiffness of system, $(\mathrm{kN} / \mathrm{mm}) ; \mathrm{E}=$ Young $\mathrm{s}$ Modulus of the material, $\left(\mathrm{kN} / \mathrm{mm}^{2}\right)$; $\mathrm{I}=$ Area moment of inertia, $\left(\mathrm{mm}^{4}\right) ; \mathrm{L}=$ Effective length of Simply Supported Beam $(\mathrm{mm})$.

The initial stiffness, secant stiffness at service load and theoretical stiffness determined as mentioned above are from Tables 6,7 , and 8 values.

Table 6. Stiffness of beams without reinforcement

\begin{tabular}{|l|c|c|c|c|}
\hline \multicolumn{1}{|c|}{ Type of concrete } & $\begin{array}{c}\text { Identification } \\
\text { of beam }\end{array}$ & $\begin{array}{c}\text { Initial stiffness, } \mathbf{k} \mathbf{i} \\
\mathbf{k N / \mathbf { m m }}\end{array}$ & $\begin{array}{c}\text { Secant stiffness } \\
\mathbf{a t ~ s e r v i c e ~ l o a d , ~} \mathbf{k s} \\
\mathbf{k N} / \mathbf{m m}\end{array}$ & $\begin{array}{c}\text { Theoretical } \\
\mathbf{s t i f f n e s s , ~} \mathbf{k} \mathbf{t} \\
\mathbf{k N} / \mathbf{m m}\end{array}$ \\
\hline Conventional Concrete & $\mathrm{A}_{1}$ & 7.015 & 25.0 & 43.5 \\
\hline $\begin{array}{l}\text { Steel Fiber Reinforced } \\
\text { Concrete }\end{array}$ & $\mathrm{B}_{1}$ & 4.912 & 35.7 & 138.7 \\
\hline $\begin{array}{l}\text { Polypropylene Fiber } \\
\text { Reinforced Concrete }\end{array}$ & $\mathrm{C}_{1}$ & 10.810 & 33.0 & 69.3 \\
\hline $\begin{array}{l}\text { Hybrid Fiber Reinforced } \\
\text { Concrete }\end{array}$ & $\mathrm{D}_{1}$ & 5.143 & 29.0 & 53.5 \\
\hline
\end{tabular}


Table 7. Stiffness of singly reinforced beams

\begin{tabular}{|c|c|c|c|c|}
\hline Type of concrete & $\begin{array}{c}\text { Identification } \\
\text { of beam }\end{array}$ & $\begin{array}{c}\text { Initial stiffness, } \mathbf{k} \mathbf{i} \\
\mathbf{k N} / \mathbf{m m}\end{array}$ & $\begin{array}{c}\text { Secant stiffness } \\
\mathbf{a t} \mathbf{s e r v i c e ~ l o a d , ~} \\
\mathbf{k s}, \\
\mathbf{k N} / \mathbf{m m}\end{array}$ & $\begin{array}{c}\text { Theoretical } \\
\mathbf{s t i f f n e s s , ~} \mathbf{k} \mathbf{t} \\
\mathbf{k N} / \mathbf{m m}\end{array}$ \\
\hline Conventional Concrete & $\mathrm{A}_{1-1}$ & 9.989 & 45.50 & 58 \\
\hline $\begin{array}{c}\text { Steel Fiber Reinforced } \\
\text { Concrete }\end{array}$ & $\mathrm{B}_{1-1}$ & 10.430 & 70.71 & 48 \\
\hline $\begin{array}{c}\text { Polypropylene Fiber } \\
\text { Reinforced Concrete }\end{array}$ & $\mathrm{C}_{1-1}$ & 0.901 & 34.15 & 76 \\
\hline $\begin{array}{c}\text { Hybrid Fiber Reinforced } \\
\text { Concrete }\end{array}$ & $\mathrm{D}_{1-1}$ & 4.703 & 72.10 & 55 \\
\hline
\end{tabular}

Table 8. Stiffness of doubly reinforced beams

\begin{tabular}{|c|c|c|c|c|}
\hline Type of concrete & $\begin{array}{c}\text { Identification } \\
\text { of beam }\end{array}$ & $\begin{array}{c}\text { Initial stiffness } k_{i} \\
\mathbf{k N} / \mathbf{m m}\end{array}$ & $\begin{array}{c}\text { Secant stiffness } \\
\text { at service load, } \mathrm{ks}_{\mathrm{s}} \\
\mathrm{kN} / \mathrm{mm}\end{array}$ & $\begin{array}{c}\text { Theoretical } \\
\text { stiffness, kt } \\
\text { kN/mm }\end{array}$ \\
\hline Conventional Concrete & $\mathrm{A}_{1-2}$ & 1.784 & 71.13 & 12 \\
\hline $\begin{array}{l}\text { Steel Fibre Reinforced } \\
\text { Concrete }\end{array}$ & $\mathrm{B}_{1-2}$ & 6.144 & 69.4 & 170 \\
\hline $\begin{array}{l}\text { Polypropylene Fibre } \\
\text { Reinforced Concrete }\end{array}$ & $\mathrm{C}_{1-2}$ & 6.857 & 56.38 & 32 \\
\hline $\begin{array}{l}\text { Hybrid Fibre Reinforced } \\
\text { Concrete }\end{array}$ & $D_{1-2}$ & 2.588 & 63 & 75 \\
\hline
\end{tabular}

NOTE $: k_{i}=$ Initial stiffness, $k_{t}=$ Theoretical stiffness of the bea, $k_{s}=$ Secant stiffness at service Load .

\subsection{COMPARISON STIFFNESS OF BEAMS WITHOUT REINFORCEMENT}

From the earlier discussions, the following points are noted by comparison of steel, polypropylene and Hybrid FRC beams with conventional concrete beams.

1. The initial stiffness of SFRC beam was $30 \%$ lower than the conventional beam.

2. The secant stiffness at service load of SFRC beam was $43 \%$ higher than the conventional beam.

3. The initial stiffness of PPFRC beams was $54 \%$ higher than the conventional beam.

4. The secant stiffness at service load of PPFRC beams was $32 \%$ higher than the conventional beam.

5. The initial stiffness of Hybrid beams was $26 \%$ lower than the conventional beam.

6. The secant stiffness at service load of Hybrid beams was $16 \%$ higher than the conventional beam. 
For all types of concrete beams, the theoretical stiffness was higher when compared to observed stiffness.

\subsection{COMPARISON OF STIFFNESS OF SINGLY REINFORCED BEAMS}

From previous discussions, following conclusions can be reached through comparison of steel, polypropylene and Hybrid beams with conventional concrete beams.

1. The initial stiffness of SFRC beam was $30 \%$ higher than the conventional beam.

2. The secant stiffness at service load of SFRC beam was $55 \%$ higher than the conventional beam.

3. The initial Stiffness of PPFRC beams was $91 \%$ higher than the conventional.

4. The secant stiffness at service load of PPFRC beams was $25 \%$ lower than the conventional beam.

5. The initial stiffness of Hybrid beams was $53 \%$ lower than the conventional beam.

6. The secant stiffness at service load of Hybrid beams was $58 \%$ higher than the conventional beam.

For all types of concrete, the theoretical stiffness is nearest in value when compared to observed stiffness

\subsection{COMPARISON STIFFNESS OF DOUBLY REINFORCED BEAMS}

From the discussions above, the following points can be made through comparison of steel, polypropylene and Hybrid beams with conventional concrete beams.

1. The initial stiffness of SFRC beam was more than $100 \%$ from the conventional beam

2. The secant stiffness at service load of SFRC beam was more or less equal to the conventional beam.

3. The initial stiffness of PPFRC beams was more than $100 \%$ higher than conventional beam

4. The secant stiffness at service load of PPFRC beams was $21 \%$ lower than the conventional beam.

5. The initial Stiffness of Hybrid beam was $47 \%$ higher than the conventional beam

6. The secant stiffness at service load of Hybrid beam was $11 \%$ lower than the conventional beam by. 
For all types of concrete beams, the theoretical stiffness was nearest in value when compared to observed stiffness.

\section{Conclusions}

The test results showed that the presence of steel and polypropylene fibers were enough to increase the strength of the concrete, however, the steel fibers had more effect.

Based on the results of this, the following conclusions are drawn:

1) The percentage of fibers used was $4 \%$ by weight of cement ( $2.14 \%$ by volume of cement) and the results were compared with the control beam specimen. Tension cracks were formed in both RC beams and FRC beams under the loaded area.

2) The ultimate deflection for the HyFRC beams was found to be increasing when compared to the control specimen, which was due to the increase in ductility of the beams by the introduction of fibers.

3) The test results showed that the ultimate deflection has significant increase when steel and polypropylene fibers were added to the concrete. Moreover, beams including steel fiber have higher ultimate deflection than the concrete prisms which included polypropylene fibers. Addition of polypropylene fiber provides more elastic properties.

4) The final collapse takes longer than plain concrete beams when fibers were added in. Addition of steel and polypropylene fibers had significant effects on the total deflection and at the same time, more fiber content in concrete decreased the deflection rate of total deflection. In addition, adding steel fiber has lower deflection than polypropylene and hybrid fibers.

5) For singly reinforced PPFRC beams initial stiffness was higher than the secant stiffness which means that the ultimate load stiffness was lower.

6) For doubly reinforced PPFRC beams initial stiffness was more than $100 \%$ but the secant stiffness was less than the initial stiffness. PPFRC is less stiff than the others. 


\section{REFERENCES}

1. S. K. Kulkarni et. al Elastic properties of R.C.C under flexural loading, International Journal of Modern Engineering Research (IJMER) Vol.2, Issue 6, Nov-Dec. 2012, pp. 4022-4025 ISSN: 2249-6645

2. Qian CX, Stroeven P. Development of hybrid polypropylene-steel fibre reinforced concrete, Cement and Concrete Research, 30 (2000) 63-9.

3. Banthia N, Nandakumar N. Crack growth resistance of hybrid fiber reinforced cement composites, Cement and Concrete Composites, 25(2003) 3-9.

4. M. N . S . H Adi An Investigation of the Behaviour of Steel and Poly propylene Fibre Reinforced Concrete Slabs 7th International Conference. Concrete: Construction's Sustainable Option - Harnessing Fibres for Concrete Construction, Dundee, Scotland, 8-10 July 2008.

5. Gonnerman HF. Effect of size and shape of test specimen on compressive strength of concrete. Proceedings ASTM 1925; 25: 237-50.

6. Markeset G, Hillerborg A. Softening of concrete in compression localization and size effects. CemConcr Res 1995;25(4):702-8.

7. Jansen DC, Shah SP. Effect of length on compressive strain softening of concrete. J EngMech ASCE 1997;123(1):25-35.

8. Fantilli AP, Ferretti D, Iori I, Vallini P. Mechanical model for failure of compressed concrete in reinforced concrete beams. J StructEng 2002;128(5):637-45.

9. Bazant ZP, Kim JK. Size effect in shear failure of longitudinally reinforced concrete beams. ACI J Proc 1984;81(5):456-68.

10. Bentz EC. Empirical modeling of reinforced concrete shear strength size effect for members without stirrups. ACI Struct J 2005;102(2):232-41.

11. Hognestad E, Hanson NW, McHenry D. Concrete stress distribution in ultimate strength design. J ACI Proc 1955;52:455-79. Also PCA Development Bulletin D6.

12. IS 10262:1982, Recommended guidelines for concrete mix Design-Bureau of Indian standards, New Delhi

13. IS $383: 1970$, Specification for coarse and fine aggregate from Natural Sources for concrete-Bureau of Indian standards, New Delhi.

14. IS:516 :1959, (Reaffirmed 1999), Indian Standard Methods of tests for Strength of concrete -Bureau of Indian standards, New Delhi

15. T. Igus, Moment of Inertia of Cracked Section, 560.325 Lecture Notes, Published by Atta Muhammad on Aug $24,2010$.

16. IS 456: 2000, Plain and Reinforced concrete - Code of Practice-Bureau of Indian standards, New Delhi. 